\title{
Data report: calcareous nannofossils and bulk calcium carbonate measurements from IODP Expedition 341, Site U1418, Gulf of Alaska'
}

\author{
Inva Braha, ${ }^{2,}{ }^{3}$ Emily Hager-Hahn, ${ }^{4}$ and Leah J. LeVay ${ }^{2}$
}

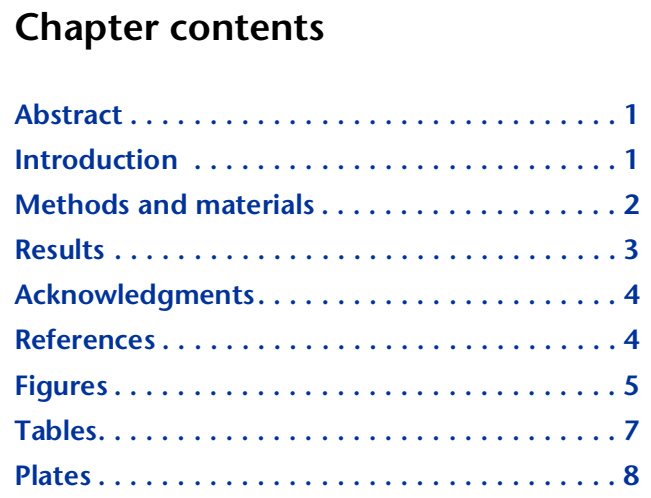

\footnotetext{
${ }^{1}$ Braha, I., Hager-Hahn, E., and LeVay, L.J., 2019. Data report: calcareous nannofossils and bulk calcium carbonate measurements from IODP Expedition 341, Site U1418, Gulf of Alaska. In Jaeger, J.M., Gulick, S.P.S., LeVay, L.J., and the Expedition 341 Scientists, Proceedings of the Integrated Ocean Drilling Program, 341: College Station, TX (Integrated Ocean Drilling Program). doi:10.2204/iodp.proc.341.205.2019 ${ }^{2}$ International Ocean Discovery Program, Texas A\&M University, College Station, Texas 77845, USA. Correspondence author: levay@iodp.tamu.edu

${ }^{3}$ Currently at: School of Earth and Environmental Sciences, Queens College, CUNY, Queens, New York 11367, USA.

${ }^{4}$ Department of Geology and Geophysics, Texas A\&M University, College Station, Texas 77845, USA.
}

\section{Abstract}

Site U1418 was cored on the Surveyor Fan in the Gulf of Alaska during Integrated Ocean Drilling Program (IODP) Expedition 341. A $949 \mathrm{~m}$ sedimentary sequence consisting of muds and diamicts was recovered. The uppermost $\sim 266 \mathrm{~m}$ contained rare intermittent occurrences of calcareous nannofossils. This interval spans approximately the last $200 \mathrm{ky}$ and potentially records environmental changes associated with glacial-interglacial cycles, making it useful for paleoceanographic reconstructions. In an effort to determine calcareous nannofossil productivity through this time interval, we studied the nannofossil assemblage and calcium carbonate $\left(\mathrm{CaCO}_{3}\right)$ weight percentage of the sediments. The nannofossil assemblage was dominated by Gephyrocapsa species and Coccolithus pelagicus. Gephyrocapsa spp. were most abundant between $\sim 100$ and $266 \mathrm{~m}$ core composite depth below seafloor (CCSF-A). Shallower than $100 \mathrm{~m}, \mathrm{C}$. pelagicus composed at least half of the assemblage. Reworked specimens of Eocene-Oligocene age were consistently observed. $\mathrm{CaCO}_{3}$ content averaged 2.77 wt $\%$ and did not display any notable trends across the study interval.

\section{Introduction}

In 2013, Integrated Ocean Drilling Program (IODP) Expedition 341 operated in the Gulf of Alaska with a program designed to study the interplay between climate, surficial process dynamics, and tectonics of the St. Elias mountain range through coring and wireline logging at five sites (Jaeger et al., 2014a). Site U1418 is located on an elevated region of the Syurveyor Fan at $3677 \mathrm{~m}$ water depth and lies below the Alaska Current, which forms the eastern boundary of the Alaska Gyre. This area has seasonal high chlorophyll concentrations that are associated with eddies in the Alaska Current (Brickley and Thomas, 2004). The positioning of Site U1418 made it possible to study both the impact of glacial-interglacial cycles on the development of the Surveyor Fan and local paleoceanography.

A total of six holes were cored at Site U1418, ranging in depth from 17.0 to 948.7 meters below seafloor (mbsf). The cores recovered a sequence of Late Pleistocene-Holocene (0-1.2 Ma) mud with interbedded silt, mud with interbedded clast-poor diamict, mud, and muddy diamict (Jaeger et al., 2014b). Several micro- 
fossil groups were present at this site, including planktonic and benthic foraminifers, diatoms, radiolarians, and calcareous nannofossils (Jaeger et al., 2014b). Calcareous nannofossils were identified intermittently in the uppermost $\sim 266$ m core composite depth below seafloor (CCSF-A) and less frequently from 266 to $600 \mathrm{~m}$ CCSF-A (Jaeger et al., 2014b).

The presence and species abundance of calcareous nannofossils reflect their affinity for particular surface water properties, such as temperature, nutrient concentrations, and salinity. Through studying the nannofossil assemblage, changes in ocean conditions and primary productivity can potentially be reconstructed. For example, the species Gephyrocapsa muellerae and Coccolithus pelagicus are both associated with cool surface waters during the Holocenerecent (Ziveri et al., 2004) and can be used as temperature proxies. The carbonate content of sediments can also provide information about calcareous plankton productivity and bottom water carbonate saturation. During Pleistocene glacial-interglacial cycles, carbonate content of deep-sea sediments has been shown to vary with climate state, impacting bottom water chemistry. One example of this comes from the southern Atlantic (Ocean Drilling Program Site 1089) where higher carbonate content is associated with glacial periods and is driven by shelf-deep sea carbonate fractionation (Hodell et al., 2001). Alternatively, the carbonate content maybe the result of surface water productivity rather than preservation.

Here we present calcareous nannofossil assemblage data, including group abundance and preservation, and calcium carbonate content for 0-266 m CCSF-A at Site U1418. This interval covers the past $\sim 200 \mathrm{ky}$ based on the shipboard age model and encompasses the last two glacial cycles. The goal of this project was to link the nannofossil record to changes in calcium carbonate deposition over glacial and interglacial intervals and to resolve interplay between primary production and climate.

\section{Methods and materials}

\section{Calcareous nannofossils}

A total of 131 samples were studied for calcareous nannofossils from the Site U1418 shipboard splice, which includes material from Holes U1418A, U1418C, U1418D, and U1418E (Jaeger et al., 2014b). Samples were prepared using a standard smear slide technique and examined using a Zeiss Axioskop microscope at $1000 \times$ magnification. Fossil counts were performed until 100 specimens were reached. Occasionally, 100 specimens could not be found in the entire slide. Typically, nannofossil assemblage counts include many more specimens to reach a robust statistical significance (300+); however, fossils were so rare in these samples that we chose a lower number of specimens that was attainable for most slides. The total number of counted nannofossils is reported in Table $\mathbf{T} 1$.

Total calcareous nannofossil abundance and preservation was visually assessed using the protocol outlined in Clemens et al. (2016).

Total calcareous nannofossil abundance was estimated as follows:

- $\mathrm{D}=$ dominant $(>90 \%$ of particles)

- $\mathrm{A}=$ abundant ( $>50 \%-90 \%$ of particles)

- $\mathrm{C}=$ common $(>10 \%-50 \%$ of particles $)$

- $\mathrm{F}=$ few $(1 \%-10 \%$ of particles)

- $\mathrm{R}=$ rare $(<1 \%$ of particles $)$

- $\mathrm{B}=$ barren (no specimens)

Preservation of calcareous nannofossils was qualitatively described as:

- $\mathrm{VG}=$ very good (no evidence of dissolution and/or recrystallization, no alteration of primary morphological characteristics, and specimens identifiable to species level).

- $\mathrm{G}=$ good (little evidence of dissolution and/or recrystallization, primary morphological characteristics only slightly altered, and specimens identifiable to species level).

- $\mathrm{M}=$ moderate (specimens exhibit some etching and/or recrystallization, primary morphological characteristics somewhat altered, and most specimens identifiable to species level).

- $\mathrm{P}=$ poor (specimens were severely etched or overgrown, primary morphological characteristics largely destroyed, fragmentation has occurred, and specimens often could not be identified to species and/or generic level).

Calcareous nannofossil taxonomy followed that of Bown (1998), Perch-Nielsen (1985), and Nannotax3 (Young et al., 2018); full taxonomic lists can be found in these references. Additional rare species that were observed while scanning the slides but not while performing the quantitative counts are illustrated in Plates P1 and P2.

The shipboard age model suggests the studied section spans the recent to $\sim 200$ ka (Jaeger et al., 2014b), during which time there are no nannofossil zonal markers (Gradstein et al., 2012). The datum Gephyrocapsa caribbeanica/Emiliania huxleyi crossover (0.09 Ma) was not observed because G. caribbeanica was not present at this site.

Gephyrocapsa species were divided based on size and morphology. Gephyrocapsa muellerae is the prominent Gephyrocapsa species in these sediments. 
Smaller forms $(<3 \mu \mathrm{m})$ of Gephyrocapsa with a visible bar across the central area were identified separately. These small forms were most likely G. ericsonii; however, we could not confidently identify these small forms without scanning electron microscopy (SEM). Specimens that had a Gephyrocapsa-like rim but were lacking the central area bar were grouped as either "Gephyrocapsa or Emiliania spp. $<3 \mu \mathrm{m}$ " or "Gephyrocapsa spp. $>3 \mu \mathrm{m}$." Under light microscopy it was very difficult to distinguish between the rims of these two genera. Our assumption is that these were gephyrocapsids missing the central bar due to preservation, but it cannot be ruled out that they were Emiliania huxleyi specimens without detailed SEM analysis.

All reworked specimens were included in the abundance counts and grouped together as "reworked fossils." These specimens were not used to classify preservation.

\section{Calcium carbonate}

Carbonate weight percent $\left(\mathrm{CaCO}_{3} \mathrm{wt} \%\right)$ was measured on 159 samples from Site U1418. Samples were first dried in a $50^{\circ} \mathrm{C}$ oven for at least $24 \mathrm{~h}$. They were then ground using a mortar and pestle and placed back in the oven for another $24 \mathrm{~h}$.

$\mathrm{CaCO}_{3}$ was determined using an UIC Inc. model $5011 \mathrm{CO}_{2}$ coulometer at the International Ocean Discovery Program at Texas A\&M University. Between 10 and $18 \mathrm{mg}$ of dried, powered sediment was weighed on a microbalance and reacted with $2 \mathrm{M}$ $\mathrm{HCl}$. The resulting $\mathrm{CO}_{2}$ was titrated and the endpoint determined by a photodetector. The liberated $\mathrm{CO}_{2}$ was assumed to be entirely from dissolved Ca$\mathrm{CO}_{3}$. The total inorganic carbon (TIC) output was given in micrograms $\mathrm{C}$, and the following equation was used to calculate $\mathrm{CaCO}_{3} \mathrm{wt} \%$ :

$$
\mathrm{CaCO}_{3} \mathrm{wt} \%=\mathrm{TIC}(\mu \mathrm{g} \mathrm{C}) \times 8.33 / \text { sample mass }(\mu \mathrm{g} \mathrm{C}) \text {. }
$$

A replicate was run after every 5 sample measurements, and a standard $\left(100 \% \mathrm{CaCO}_{3}\right)$ was run after every 10 measurements to check for instrumental drift.

\section{Results}

\section{Calcareous nannofossil assemblage}

A complete list of qualitative total nannofossil abundance, relative abundance, and fossil preservation is presented in Table T1.

Nannofossils were barren to present in rare abundance from the top of the section to 140 m CCSF-A (Fig. F2A). Below this depth the frequency of barren intervals increased. Two main intervals were observed that contain few, if any, nannofossils: 142$168 \mathrm{~m}$ and 248-262 m CCSF-A. Fossil preservation was poor to moderate, with only six samples containing fossils that were moderate-good to good (Fig. F2B). The number of fossils counted on each slide decreased with nannofossil abundance and preservation (Fig. F2C).

The dominant taxa were Coccolithus pelagicus and Gephyrocapsa spp., which included G. muellerae, Geophyrocapsa spp. $<3 \mu \mathrm{m}$, Gephyrocapsa/Emiliania spp. $<3 \mu \mathrm{m}$, and Gephyrocapsa spp. > $3 \mu \mathrm{m}$ (Fig. F2D, F2E). The abundance of Gephyrocapsa/Emiliania spp. $<3 \mu \mathrm{m}$ and Gephyrocapsa spp. $>3 \mu \mathrm{m}$ were influenced by the preservation of the sample and the loss of the central bar with dissolution. The abundance patterns of Coccolithus and Gephyrocapsa co-varied, likely the result of a closed-sum effect. Coccolithus pelagicus was most abundant in the upper $96 \mathrm{~m}$ CCSFA. Below this depth, the assemblage was dominated by Gephyrocapsa spp., which composed up to $95 \%$ of the individuals.

Other taxa included in the counts were Pontosphaera spp. and Cruciplacolithus neohelis.

Reworked specimens made up an average of 7 specimens per 100 fossils and peaked at 42 individuals in Sample 341-U1418C-24H-4W, 31-35 cm (Fig. F2F). These reworked fossils included Reticulofenestra dictyoda, R. bisecta, R. daviesii, R. umbilicus, Chiasmolithus oamaruensis, Isthmolithus recurvus, Cyclicargolithus floridanus, Pontosphaera pulchra, and Toweius spp. (Plates P1, P2). This reworked assemblage indicated an age of Eocene-Oligocene (56-23 Ma) and was consistent with fossils found in dredge samples from deep-sea outcropping beds along the continental margin, southeast of Site U1418 (Plafker et al., 1985). The outcrops provide a likely source for the reworked specimens.

\section{Bulk carbonate}

Measured $\mathrm{CaCO}_{3}$ ranged $0.03-9.56$ wt $\%$ with an average concentration of $2.77 \mathrm{wt} \%$ (Table T2). A total of 26 replicate samples were measured with an average resulting difference of $\pm 0.31 \%$.

There were slight trends in $\mathrm{CaCO}_{3}$ of the sediments downcore (Fig. F3). The uppermost $\sim 100 \mathrm{~m}$ CCSF-A contained values averaging $2.94 \mathrm{wt} \%$; values gradually decreased downcore to $\sim 2 \mathrm{wt} \%$. At $\sim 100 \mathrm{~m}$ CCSF-A, carbonate values increased to $\sim 3 \mathrm{wt} \%$ and decreased to $\sim 1.5 \mathrm{wt} \%$ at $\sim 186 \mathrm{~m}$ CCSF-A. Below $\sim 186 \mathrm{~m}$ CCSF-A, carbonate values increased again and the base of the measured section ( 186-266.2 m CCSF-A) had an average $\mathrm{CaCO}_{3}$ concentration of $\sim 3$ 
wt $\%$. These trends in $\mathrm{CaCO}_{3}$ were broadly matched by the abundance of Gephyrocapsa spp. (Fig. F2).

\section{Acknowledgments}

We would like to acknowledge the science party, technical staff, and crew of Integrated Ocean Drilling Program Expedition 341. Sediment samples were provided by the IODP Gulf Coast Repository. This manuscript benefited greatly from the review of Cherry Newsam, and we thank her for her insightful comments. This work was funded through an IODP U.S. Science Support Program Post-Expedition Activity Award to L.J. LeVay and by NSF Grant OCE1326927.

\section{References}

Bown, P.R. (Ed.), 1998. Calcareous Nannofossil Biostratigraphy: New York (Springer).

Brickley, P.J., and Thomas, A.C., 2004. Satellite-measured seasonal and inter-annual chlorophyll variability in the Northeast Pacific and Coastal Gulf of Alaska. Deep Sea Research II: Topical Studies in Oceanography, 51(1-3):229_ 245. https://doi.org/10.1016/j.dsr2.2003.06.003

Clemens, S.C., Kuhnt, W., LeVay, L.J., Anand, P., Ando, T., Bartol, M., Bolton, C.T., Ding, X., Gariboldi, K., Giosan, L., Hathorne, E.C., Huang, Y., Jaiswal, P., Kim, S., Kirkpatrick, J.B., Littler, K., Marino, G., Martinez, P., Naik, D., Peketi, A., Phillips, S.C., Robinson, M.M., Romero, O.E., Sagar, N., Taladay, K.B., Taylor, S.N., Thirumalai, K., Uramoto, G., Usui, Y., Wang, J., Yamamoto, M., and Zhou, L., 2016. Expedition 353 methods. In Clemens, S.C., Kuhnt, W., LeVay, L.J., and the Expedition 353 Scientists, Indian Monsoon Rainfall. Proceedings of the International Ocean Discovery Program, 353: College Station, TX (International Ocean Discovery Program). https://doi.org/10.14379/iodp.proc.353.102.2016

Gradstein, F.M., Ogg, J.G., Schmitz, M.D., and Ogg, G.M. (Eds.), 2012. The Geological Time Scale 2012: Amsterdam (Elsevier). https://doi.org/10.1016/C2011-1-08249-8

Hodell, D.A., Charles, C.D., and Sierro, F.J., 2001. Late Pleistocene evolution of the ocean's carbonate system. Earth and Planetary Science Letters, 192(2):109-124. https://doi.org/10.1016/S0012-821X(01)00430-7

Jaeger, J.M., Gulick, S.P.S., LeVay, L.J., Asahi, H., Bahlburg, H., Belanger, C.L., Berbel, G.B.B., Childress, L.B., Cowan, E.A., Drab, L., Forwick, M., Fukumura, A., Ge, S., Gupta, S.M., Kioka, A., Konno, S., März, C.E., Matsu- zaki, K.M., McClymont, E.L., Mix, A.C., Moy, C.M., Müller, J., Nakamura, A., Ojima, T., Ridgway, K.D., Rodrigues Ribeiro, F., Romero, O.E., Slagle, A.L., Stoner, J.S., St-Onge, G., Suto, I., Walczak, M.H., and Worthington, L.L., 2014a. Expedition 341 summary. In Jaeger, J.M., Gulick, S.P.S., LeVay, L.J., and the Expedition 341 Scientists, Proceedings of the Integrated Ocean Drilling Program, 341: College Station, TX (Integrated Ocean Drilling Program). https://doi.org/10.2204/

iodp.proc.341.101.2014

Jaeger, J.M., Gulick, S.P.S., LeVay, L.J., Asahi, H., Bahlburg, H., Belanger, C.L., Berbel, G.B.B., Childress, L.B., Cowan, E.A., Drab, L., Forwick, M., Fukumura, A., Ge, S., Gupta, S.M., Kioka, A., Konno, S., März, C.E., Matsuzaki, K.M., McClymont, E.L., Mix, A.C., Moy, C.M., Müller, J., Nakamura, A., Ojima, T., Ridgway, K.D., Rodrigues Ribeiro, F., Romero, O.E., Slagle, A.L., Stoner, J.S., St-Onge, G., Suto, I., Walczak, M.H., and Worthington, L.L., 2014b. Site U1418. In Jaeger, J.M., Gulick, S.P.S., LeVay, L.J., and the Expedition 341 Scientists, Proceedings of the Integrated Ocean Drilling Program, 341: College Station, TX (Integrated Ocean Drilling Program). https://doi.org/10.2204/iodp.proc.341.104.2014

Lim, E., Eakins, B.W., and Wigley, R., 2011. Coastal Relief Model of Southern Alaska: Procedures, Data Sources and Analysis. NOAA Technical Memorandum NESDIS NGDC-43. ftp://ftp.library.noaa.gov/noaa_documents.lib/NESDIS/NGDC/TM/NOAA_TM_NESDIS_NGDC_43.pdf

Perch-Nielsen, K., 1985. Cenozoic calcareous nannofossils. In Bolli, H.M., Saunders, J.B., and Perch-Nielsen, K. (Eds.), Plankton Stratigraphy: Cambridge, United Kingdom (Cambridge University Press), 427-554.

Plafker, G., Keller, G., Barron, J.A., and Blueford, J.R., 1985. Paleontologic data on the age of the Orca Group, Alaska. USGS Open-File Report, 85-429. https://doi.org/10.3133/ofr85429

Young, J.R., Bown, P.R., and Lees, J.A. (Eds.). Nannotax3. Accessed 22 August 2018. http://www.mikrotax.org/Nannotax3/

Ziveri, P., Baumann, K.-H., Böckel, B., Bollman, J., and Young, J.R., 2004. Biogeography of selected Holocene coccoliths in the Atlantic Ocean. In Thierstein, H., and Young, J. (Eds.), Coccolithophores: From Molecular Processes to Global Impact: Berlin (Springer Verlag), 403428. https://doi.org/10.1007/978-3-662-06278-4_15

Initial receipt: 12 March 2019

Acceptance: 26 September 2019

Publication: 11 December 2019

MS 341-205 
Figure F1. Location of Site U1418 in the Gulf of Alaska.

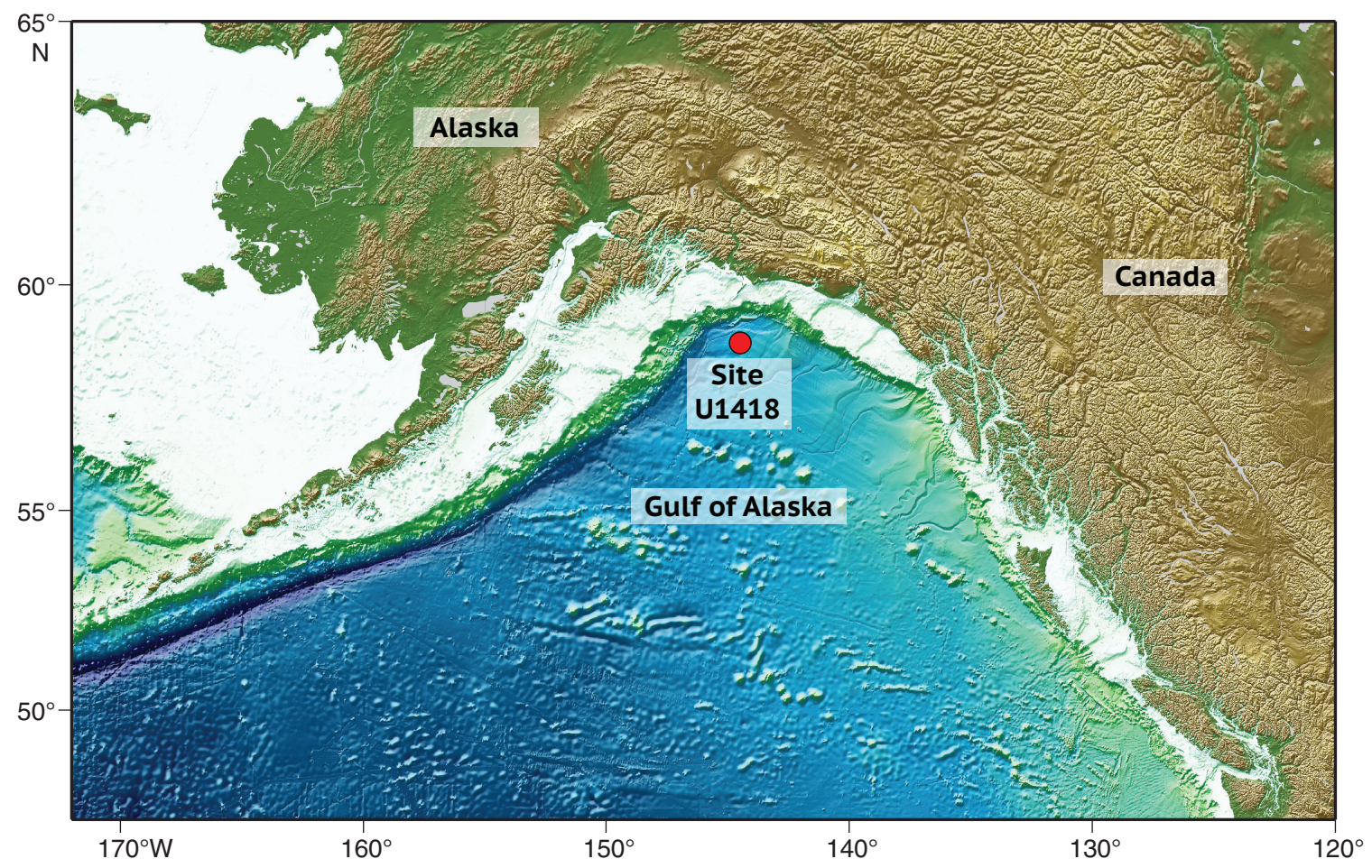

Figure F2. Nannofossil and carbonate weight percentage results plotted on the Site U1418 shipboard stratigraphic splice (m CCSF-A). A. Qualitative nannofossil abundance. B. Nannofossil preservation ( $\mathrm{P}=$ poor, $\mathrm{M}=$ moderate, $\mathrm{G}=$ good). C. Number of nannofossil specimens counted in each sample. D-F. Number of Coccolithus pelagicus, Gephyrocapsa spp., and reworked fossils counted. G. Calcium carbonate weight percentage (open triangles $=$ replicate measurements).

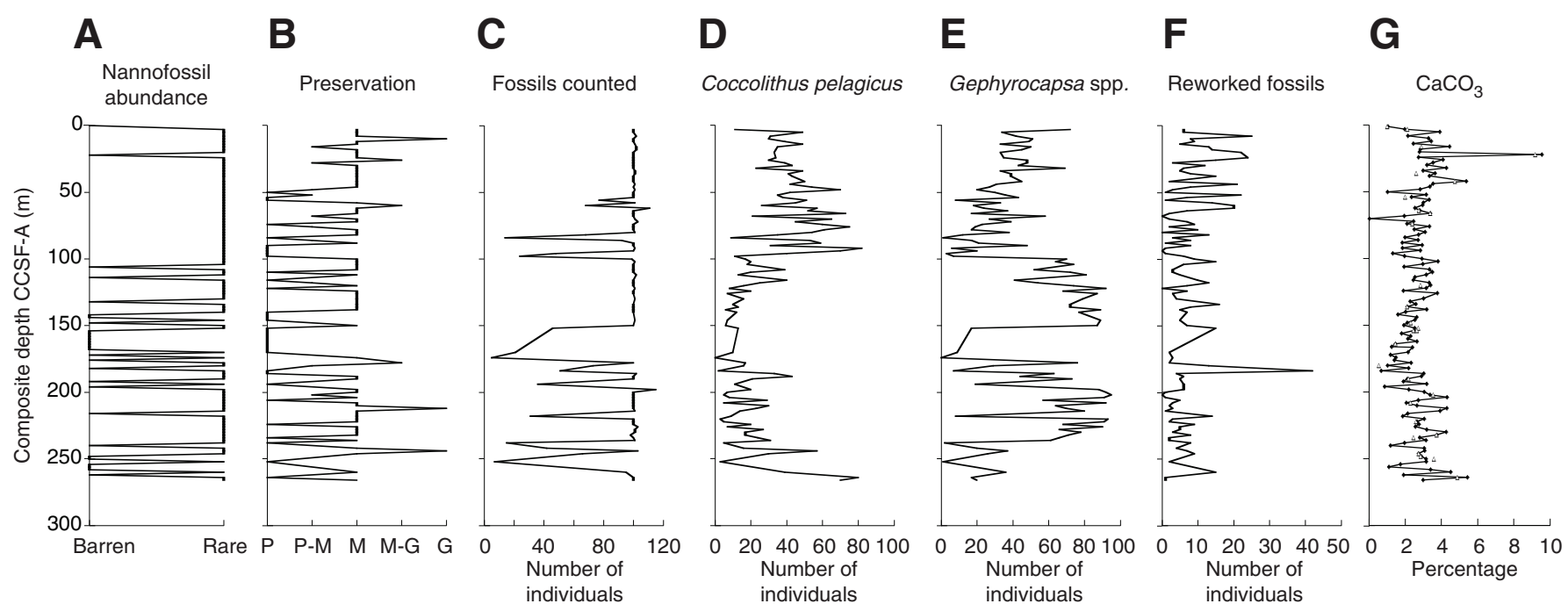


Figure F3. Carbonate weight percentages measured from Site U1418. Values are plotted on the shipboard stratigraphic splice $(\mathrm{m}$ CCSF-A). Open triangles = replicate measurements.

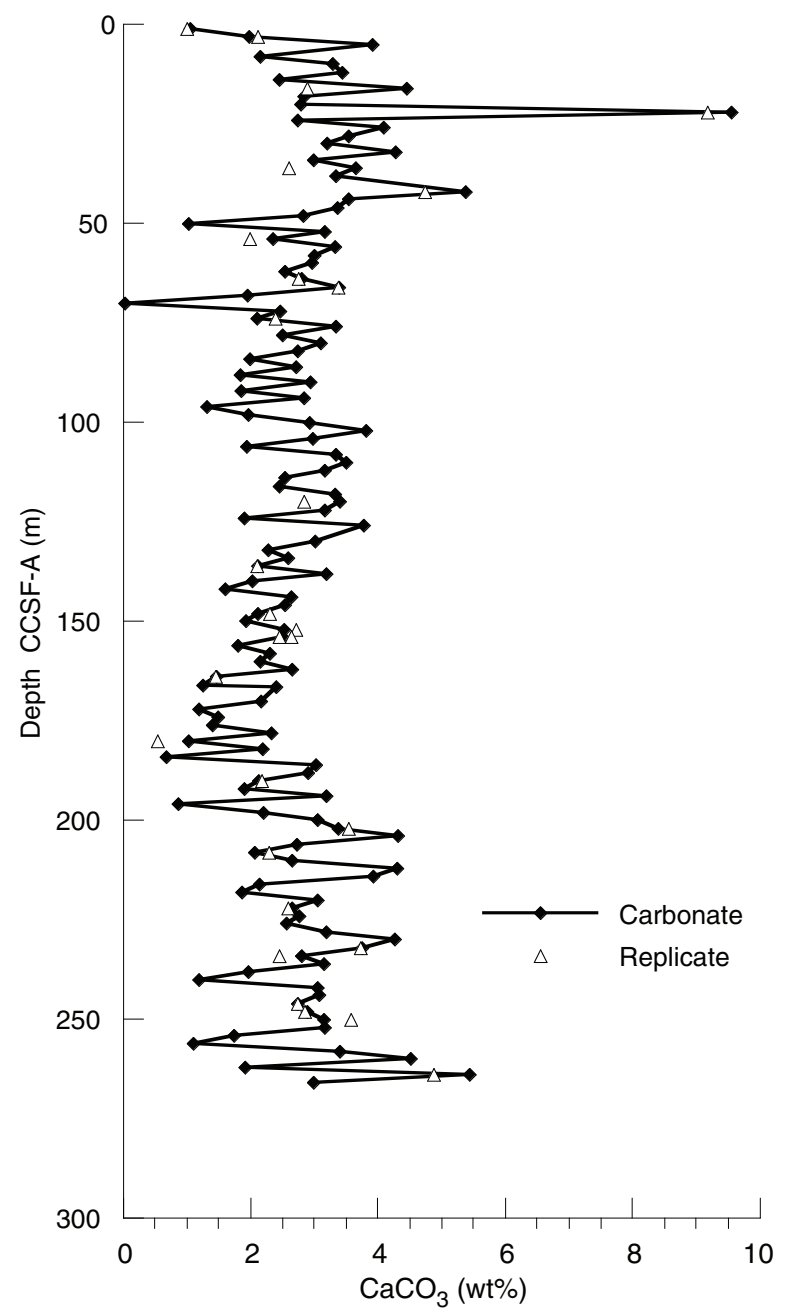


Table T1. Nannofossil counts from Site U1418. Note: $B=$ barren, $\mathrm{R}=$ rare, $\mathrm{P}=$ poor, $\mathrm{M}=\mathrm{moderate}$, and $\mathrm{G}=$ good. This file is available in CSV format.

Table T2. Calcium carbonate weight percentages from Site U1418. Sample mass ( $\mu$ g) is the weight of the measured sample. Micrograms C is the total inorganic carbon output. This file is available in CSV format. 
Plate P1. 1. Coccolithus pelagicus, $10 \mu \mathrm{m}$ (341-U1418E-2H-5W, 21-25 cm). 2. Coccolithus pelagicus, $9 \mu \mathrm{m}(341-$ U1418D-7H-3W, 36-40 cm). 3. Coccolithus braarudi, 9 um (341-U1418C-4H-3W, 96-100 cm). 4. Cruciplacolithus neohelis, $10 \mu \mathrm{m}$ (341-U1418C-4H-3W, 96-100 cm), 5. Cruciplacolithus neohelis, $8 \mu \mathrm{m}$ (341-U1418D-4H-3W, 136$140 \mathrm{~cm})$. 6. Braarudosphaera bigelowii, $6 \mu \mathrm{m}(341-\mathrm{U} 1418 \mathrm{C}-3 \mathrm{H}-3 \mathrm{~W}, 146-150 \mathrm{~cm}) .7$. Gephyrocapsa muellerae, $3 \mu \mathrm{m}$ (341-U1418C-28H-4W, 16-20 cm). 8. Gephyrocapsa or Emiliania small $(<3 \mu \mathrm{m}), 2.5 \mu \mathrm{m}(341-\mathrm{U} 1418 \mathrm{C}-4 \mathrm{H}-5 \mathrm{~W}$, 6-10 cm). 9. Gephyrocapsa spp. (>3 $\mu \mathrm{m}), 4 \mu \mathrm{m}(341-\mathrm{U} 1418 \mathrm{C}-17 \mathrm{H}-1 \mathrm{~W}, 146-150 \mathrm{~cm}) .10$. Reticulofenestra dictyoda, $7 \mu \mathrm{m}$ (341-U1418C-23H-4W, 136-140 cm; reworked specimen). 11. Reticulofenestra bisecta, $4.5 \mu \mathrm{m}$ (341U1418D-23H-2W, 69-73 cm; reworked specimen). 12. Pontosphaera pulchra, 6 um (341-U1418C-4H-3W, 96-100 $\mathrm{cm}$; reworked specimen). 13. Reticulofenestra daviesii, $7 \mu \mathrm{m}$ (341-U1418D-9H-2W, 36-40 cm; reworked specimen). 14. Reticulofenestra umbilicus, $15 \mu \mathrm{m}$ (341-U1418D-22H-3W, 94-98 cm; reworked specimen). 15. Reticulofenestra spp., $8 \mu \mathrm{m}$ (341-U1418C-3H-3W, 146-150 cm; reworked specimen). (Continued on next page.) 
Plate P1. (continued). Caption on previous page.
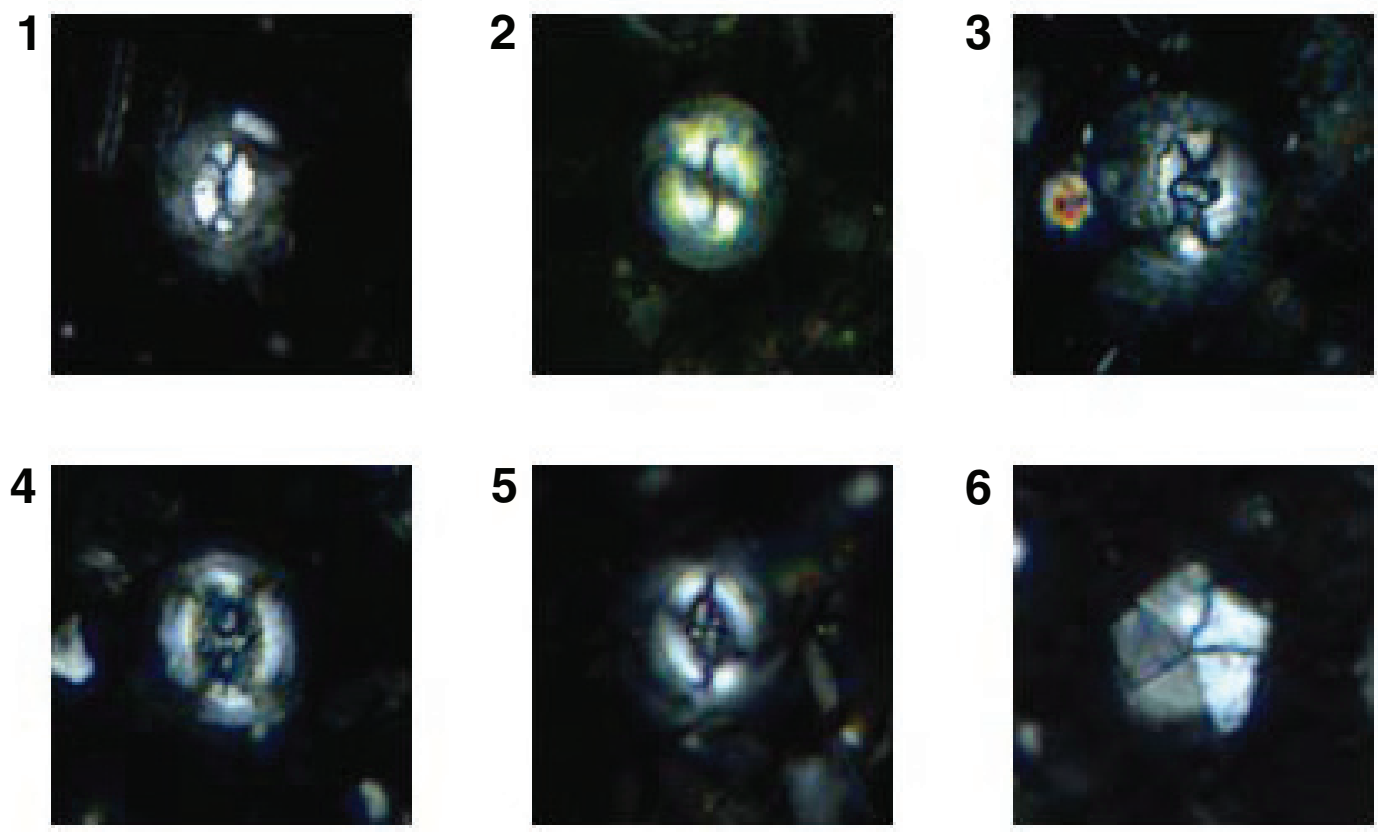

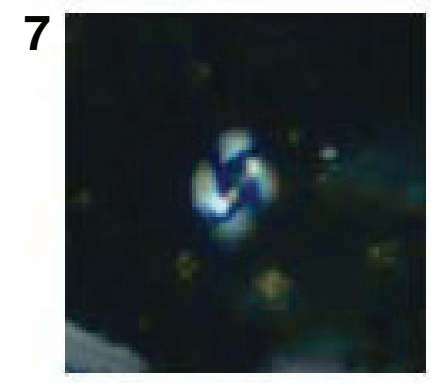

8

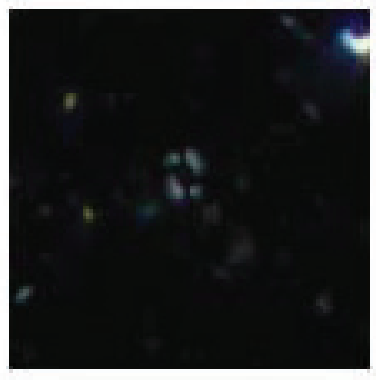

10

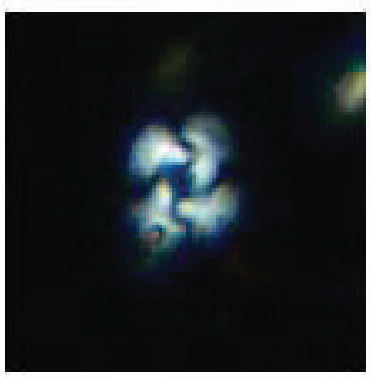

13

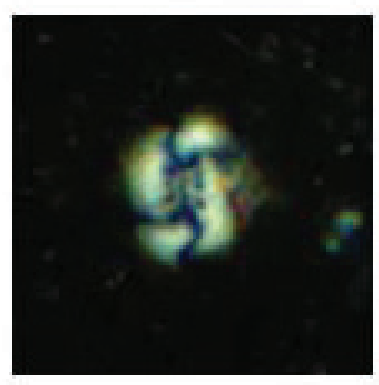

11

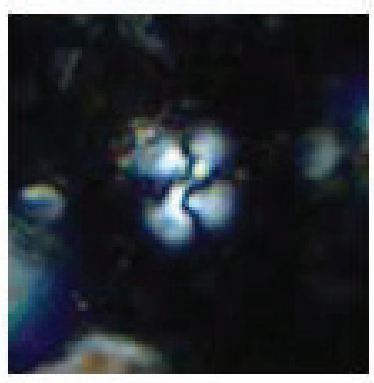

14

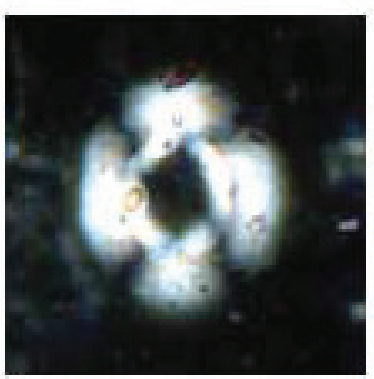

9

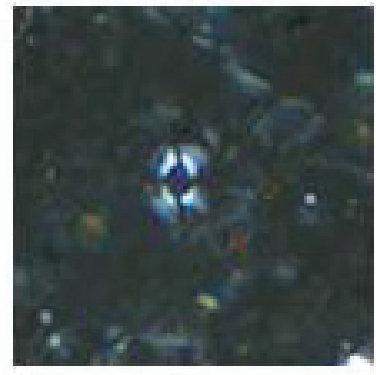

12

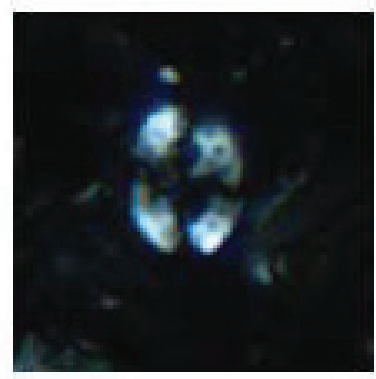

15

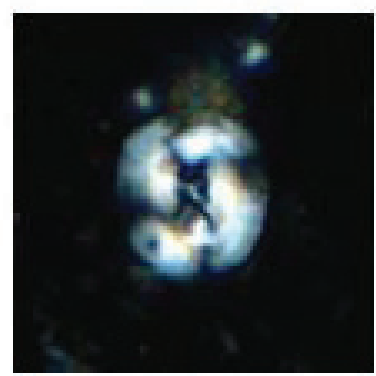


Plate P2. 1. Chiasmolithus oamaruensis, $15 \mu \mathrm{m}$ (341-U1418D-3H-3W, 6-10 cm; reworked specimen). 2. Isthmolithus recurvus, $9 \mu \mathrm{m}$ (341-U1418C-27H-3W, 136-140 cm; reworked specimen). 3. Cyclicargolithus floridanus, $6 \mu \mathrm{m}$ (341-U1418D-4H-5W, 36-40 cm; reworked specimen). 4. Toweius spp., 5 rm (341-U1418C-4H-3W, 96$100 \mathrm{~cm}$; reworked specimen).
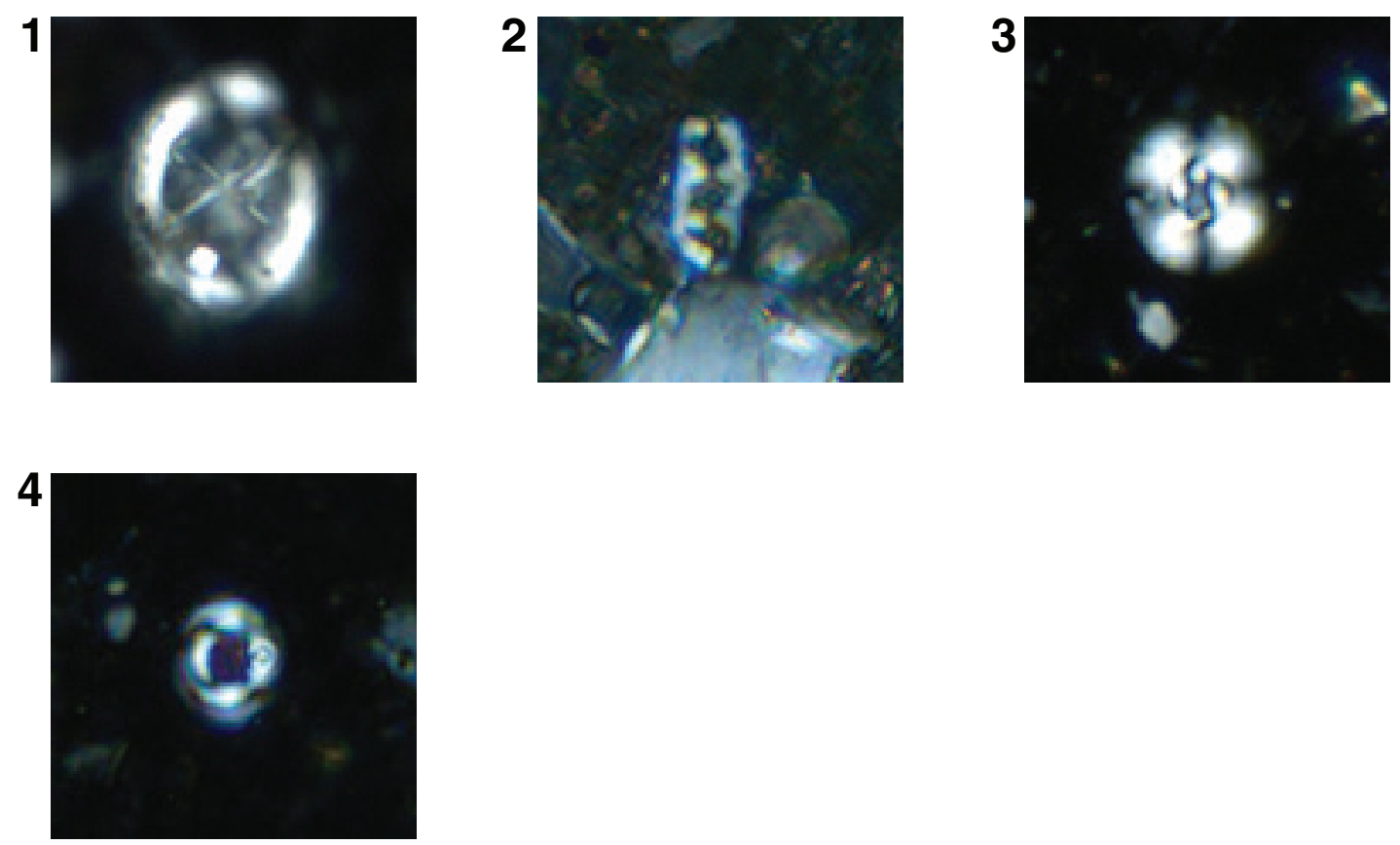